\title{
Formulary Apportionment in the European Union
}

\author{
Estefanía López Llopis*
}

\begin{abstract}
The European proposal on a Common Consolidated Corporate Tax Base suggests a sharing mechanism based on the application of an apportionment formula. This formula includes three different factors (labour, assets and sales) with equal weighting. Despite the virtues of this method, we believe that the suggested formula is far from being consistent from an economic point of view and that European institutions should revise it before continuing with the negotiation process. In order to design a new formula, it is vital to take into consideration the objectives of the European proposal and the growing concern about the phenomenon of profit shifting in the EU context. In the light of these premises, two different alternatives are analysed in this article. On the one hand, we refer to the possibility of using a two-factor formula for distributing the tax base amongst Member States, based on assets and labour as productive factors. On the other, we suggest a formula exclusively based on sales as an income-generating factor. Although both alternatives are far from being perfect, we conclude that a single-sales factor formula offers a large number of advantages and is an efficient method to fight against profit shifting strategies.
\end{abstract}

\section{INTRODUCTION}

In 1998, the conclusions of the Economic and Financial Affairs Council (ECOFIN Council) that took place in December included a request to the European Commission (EC) to carry out an analytical study regarding company taxation in the European Union (EU). In the first place, this study was to expose existing differences in effective corporate tax rates amongst Member States (MS). Secondly, it should identify those fiscal questions that could be hampering cross-border economic activity.

\section{I.I Tax Obstacles in the Internal Market}

In 2001, the EC launched the report Company taxation in the internal market, which highlighted the existence of big differentials in effective levels of corporate tax rates amongst MS. ${ }^{1}$ According to the report, taxation is only one of the variables that may influence companies' investment and location decisions. However, the high dispersion amongst effective tax rates seemed to be affecting companies' competitiveness. Moreover, these differentials represented an incentive to invest in the most favourable areas from a fiscal perspective. Therefore, they could be resulting in an inefficient location of resources and, consequently, in losses of welfare.
On the other hand, the EC's study identified a great number of tax obstacles to cross-border economic activity in the internal market. In addition to other negative consequences, the report insisted on the fact that the coexistence of fifteen different tax systems in the EU context justified the use of separate accounting and the arm's length principle in order to distribute companies' income amongst MS for tax purposes. Despite the goodness and advantages of this valuation system, the economic scenario in 2001 had experienced a high number of changes and great progress since it was designed. The use of this system in such a different context was creating new problems, such as high compliance costs for companies, high control and management costs for public authorities, risk of double taxation and risk of tax evasion through manipulation of transfer prices.

\section{I.2 Targeted Measures and Comprehensive Approaches}

As possible solutions to all these problems, the report made a distinction between two different approaches. On the one hand, the Commission referred to particular solutions that would contribute to solve most of the problems in an isolated way. ${ }^{2}$ On the other, the EC talked about

\section{Notes}

Teaching Assistant of the Department of Applied Economics at the University of Alicante (Spain). Email: esteui86@gmail.com/estefania.lopez@ua.es.

Commission Staff Working Paper, Company Taxation in the Internal Market (2001).

For instance, the Commission suggested modifying the Mergers Directive, improving the application of the Arbitration Convention and covering the gaps in the current network of Double Taxation Conventions. 
wider solutions to directly tackle the origin of those problems (and not the problems themselves). Seemingly, the second proposal would bring about the most advantages. ${ }^{3}$

In the EC's opinion, opting for a comprehensive approach would provide MS with a common consolidated corporate tax base (CCCTB). Therefore, it would eliminate a great number of the existing obstacles all at once. As long as companies no longer had to deal with fifteen different tax systems, a CССТВ would mean a great number of benefits. For instance, it would imply a significant reduction of compliance costs for companies, more efficiency in companies' location decisions, less risk of double taxation, less risk of tax evasion, and, in general, more simplicity, both for companies and tax administrations.

In line with the EC's description, the introduction of a CСCTB in the EU would eliminate the problem of high dispersion in the existing regulatory framework. Instead of fifteen different tax systems, there would only be one common set of rules to calculate corporate tax base. As a second step, the corporate tax base would be distributed amongst MS where multinational companies and cross-border groups of companies carry out their economic activities. This distribution would be done according to a sharing mechanism commonly agreed by MS. Finally, each MS would apply its own corporate tax rate in order to tax the specific amount of the company's profit generated in its territory. As long as each MS could decide about applicable tax rates, this approach would be, in one way or another, respectful of MS sovereignty in the field of direct taxation.

\section{THE PROPOSAL FOR A DIRECTIVE ON A COMMON CONSOLIDATED CORPORATE TAX BASE (ССCTB) IN THE EUROPEAN UNION}

\section{I Overview}

The first proposal for a Directive on a CCCTB in the EU was launched in $2011 .{ }^{4}$ Up to the present, however, this proposal has not led to any successful results and remains at a standstill. This is mainly because it will imply a major change in the existing set of rules, so that MS have found great difficulties in reaching an agreement in this context.

In an attempt to accelerate the decision making process, the EC decided to launch a new proposal on a CCCTB in October 2016. The main novelty of the new proposal is that it consists of two different Directives that will be introduced progressively. Firstly, European institutions hope to approve a Directive for a Common Corporate Tax Base (CCTB) in the EU. After that, the approval of a Directive for a CCСТB will follow.

\subsection{Objectives}

According to the Introduction of the recent proposal for a Directive on a CCCTB:

the CCCTB features as an effective tool for attributing income to where the value is created, through a formula based on three equally weighted factors (i.e. assets, labour, and sales). Since these factors are attached to where a company earns its profits, they are more resilient to aggressive tax planning practices than the widespread transfer pricing methods for allocating profit.

We conclude that the main purpose of the CCCTB is to replace transfer pricing, which has been proved to be ineffective nowadays, with a different method for allocating income. Such a change is necessary since transfer pricing does not seem to fit in well with the current economic scenario. Among other reasons because it:

is not suited with the global nature of international business. In particular, international production processes make the separate accounting system (SA) of assigning profit to specific geographic destinations inherently arbitrary. (...) with firms that are truly integrated across borders, holding related entities at an 'arms-length' standard for the pricing of intra company transactions does not make sense, nor does allocating income and expenses on a country-by country basis. $^{6}$

Closely related to the general purpose, it is possible to distinguish two specific objectives in the EC's proposal.

\section{Notes}

Regarding the advantages of harmonization, see James M. Poterba, Massachusetts: National Bureau of Economic Research Tax Policy and the Economy § 5.181-184 (2007). European Commission, Proposal for a Council Directive on a Common Consolidated Corporate Tax Base (2011).

In Oct. 2016, the European Commission proposed to re-launch the CССТВ. Given that the original proposal proved too ambitious for MS to agree in one go, the Commission decided to re-launch it through a more manageable process. As one of the key changes, the new proposal on a CCCTB is expected to be implemented in two steps. In the first step, the common base should be implemented. Afterwards, consolidation should be put in place.

Reuven S. Avi-Yonah \& Kimberly A. Clausing, A Proposal to Adopt Formulary Apportionment for Corporate Income Taxation. The Hamilton Project, 85 Pub. L. \& Legal Theory W. P. S. 6 (2007). Other problems associated with the application of transfer pricing system in the current economic scenario are described in the following pages of the same paper. See also Reuven S. Avi-Yonah, Between Formulary Apportionment and the OECD Guidelines: A Proposal for Reconciliation, 102 L. \& Econ. W. P. 8-11 (2009). 
On the one hand, the CCCTB is expected to help European institutions in their fight against profit shifting and tax evasion. Given that transfer pricing offers great opportunities for manipulation, both the risk of profit shifting and the risk of tax evasion are directly related to the use of this method for allocating income. On the other hand, the CССТВ proposal hopes to ensure that companies' profits are taxed where they have effectively been earned. Undoubtedly, both specific goals are highly linked to each other. As experience has demonstrated, profit-shifting strategies lead to a situation where companies' profits are not taxed where they should be taxed, but in those territories where companies want profits to be taxed. Therefore, alleviating the problem of profit shifting (first goal) would help to ensure that companies' income is effectively taxed where value is generated.

\subsection{The Sharing Mechanism as a Key Element of the Proposal}

Undoubtedly, the sharing mechanism is one of the key elements in the Commission's proposal. Mainly because its application will determine which MS are competent to tax cross-border companies' income and to what extent. Therefore, it is also an extremely delicate element of the proposal on a CССТВ. Aware of this fact, European institutions have repeatedly pointed out that the sharing mechanism must be fair, equitable, neutral and not liable to being manipulated.

In 2011, once other important issues about the first proposal had been discussed, the EC began a round of debates with MS in order to reach a decision about the sharing mechanism. As a starting point to these debates, a basic distinction was made between a macro-level approach and two micro-level approaches: value-added approach and formulary apportionment approach. Afterwards, advantages and disadvantages of each alternative were discussed.

After the first round of debates, the EC concluded that all the alternatives had weaknesses and flaws, so that there was no evidence to confirm that one of them was better than the others. According to this institution, however, it was vital to take into consideration that formulary apportionment had traditionally been used (apparently with satisfying results) in the US and Canada in order to distribute companies' profits amongst states for tax purposes. ${ }^{7}$ Since then, all the debates about the sharing mechanism carried out in the European context have exclusively focused on the design of an apportionment formula. This implies not only choosing and defining the factors liable to be used, but also deciding on the specific weight that should be given to each one of these factors. Moreover, the:

choice of apportionment formula involves the balancing of several objectives, including (a) the reflection of where income originates, (b) the distortion of decisions on the location of economic activities, (c) the likelihood of tax competition (...), (d) the risk that the taxpayer will manipulate apportionment factors to shift income to low-tax member states, (e) the distribution of revenues among member states, and (f) the ease of implementation. ${ }^{8}$

\section{The EXPERIENCE IN THE US STATES}

Almost as soon as corporate income tax was introduced in the US, problems associated with taxation of cross-border companies appeared. As it happens in the EU, these problems were mainly caused by the lack of a uniform tax legislation.

\section{I The So-Called Massachusetts Formula}

The first effort to design a multistate tax system for the US dates from 1915, although it was in 1950 when public authorities made the decision to design a fair and uniform mechanism to distribute companies' profits amongst American states. The result of this process was the Uniform Division of Income for Tax Purposes Act (UDITPA), ${ }^{9}$ which recommended using the so-called Massachusetts Formula. This formula was based on three different factors with identical weights: the proportion of assets located in the state, the proportion of sales to resident customers and the proportion of wages paid to resident workers.

As a starting point in the designing process of the sharing formula, it was assumed that it is impossible to find out which precise parts of a company generate each dollar of income, regardless of in which specific states those parts of the company are located. From this point of view, the three factors finally chosen were conceived as useful indicators to approximate the fraction of the company's profit that derives from the economic activity carried out in each state. In part, the possibility of reaching a reasonable approximation was due to the fact that these factors 'reflect how income is generated and

\section{Notes}

Common Consolidated Corporate Tax Base Working Group, The Mechanism for Sharing the CCCTB 5 (2006).

Poterba, supra n. 3, at 168 .

9 Uniform Division of Income for Tax Purposes Act, drafted by the National Conference of Commissioners on Uniform State Laws and approved by the American Bar Association at its meeting at New York, 16 July 1957. 
recognize the contributions to income made by manufacturing and marketing states'. ${ }^{10}$

Initially, UDITPA's recommendation was to assign the same weight to each of the three chosen factors. ${ }^{11}$ Bearing in mind the kind of problems generated by the lack of a uniform tax legislation (especially the high risk of double taxation), the application of the same formula all around the country would mean a great step to ensure that profits of cross-border companies were effectively taxed in the US, but only once.

\subsection{Recent Trends in the US}

Over time, however, American states have introduced changes and variations in the initially recommended formula. Although it has been a long process, all of these states have moved in the same direction, giving more weight to sales. Nowadays, the vast majority of American states use a formula that gives double weight, or even more than double, to sales factor. Some of them, in fact, use a formula exclusively based on sales (commonly called single-sales factor formula). The following Table 1 reflects the US's current scenario from the point of view of apportionment formulas effectively employed.

The question that emerges is: why American states prefer using sales-factor orientated formulas? This question is not difficult to answer if we take into consideration that, according to general opinion, increasing the weight of sales in the formula leads to important economic advantages with minimum political cost. ${ }^{12}$ In 1977 , furthermore, McLure demonstrated that, under certain conditions, the apportionment formula turns corporate income tax into a tax on the factors included in the formula. ${ }^{13}$ In the light of this assertion, many states have concluded that reducing the weight of assets and wages in the formula could lead to important advantages from the point of view of employment and companies' investment. On top of that, as assets and wages are prone to manipulation by companies, reducing the role these factors play in the process of distributing the tax base could also have positive consequences from the perspective of economic growth and social welfare. ${ }^{14}$

\section{THE CCCTB APPORTIONMENT FORMULA}

\section{I Description}

Both the first EC proposal and the second one suggest a sharing mechanism based on the application of a threefactor formula. This formula includes three different factors with equal weighting: assets, sales and labour. Although it shows great similarity with the Massachusetts formula, two important differences between them must be pointed out. The first one refers to the labour factor, while the second is related to the weight of the factors included in the formula.

As for the labour factor, UDITPA's recommended formula only considered wages that companies pay for resident workers. In contrast, the European proposal not only takes into consideration the amount of wages paid to workers, but also the number of employees in each MS. This new factor is expected to play an adjustment role, since wage differences between MS can produce distortions when it comes to dividing companies' income amongst them on the grounds of the labour factor. ${ }^{15}$

Regarding the second difference, the CCCTB proposal prohibits MS from changing the weight of the factors included in the formula, as it happens in the US. While the Massachusetts formula only recommends American states to use three equally weighting factors, the European makes it compulsory MS to do this. As the American experience has shown, states find incentives to deviate from the initially recommended formula. ${ }^{16}$ The EC's objective when reducing MS' scope for action, therefore, would consist of avoiding the risk of double taxation or double non-taxation in the field of business income. Obviously:

Under a system of individually-determined factor weights per jurisdiction, more or less than $100 \%$ of the overall group tax base can be subject to taxation. (...) By contrast, the common system does not produce tax base uncertainty since all jurisdictions are bound to apply exactly the same formula. Hence, even if jurisdictions agree on changing their common apportionment formula, it is still guaranteed that exactly $100 \%$ of the overall group tax base is tax-liable. ${ }^{17}$

\section{Notes}

10 Joann M. Weiner, Formulary Apportionment and the Future of Company Taxation in the European Union, 3(1) CESifo Forum 17 (2002).

11 According to UDITPA, s. 9, 'All business income shall be apportioned (...) by multiplying the income by a fraction, the numerator of which is the property factor plus the payroll factor plus the sales factor, and the denominator of which is three.' The key element, as we can see, is 'shall', commonly used to make a suggestion.

12 A general criticism of this thesis can be found in Michael Mazerov, The 'Single Sales Factor' Formula for State Corporate Taxes. A Boon to Economic Development or a Costly Giveaway? Washington D.C.: Center on Budget and Policy Priorities (2005)

13 Charles E. McLure, State Corporate Income Tax: Lambs in Wolves' Clotbing?, 25 OTA Paper (1977).

14 See Charles E. McLure \& Walter Hellerstein, Does Sales-Only Apportionment Violate International Trade Rules?, 96(11) Tax Notes 1516 (2002).

15 See Charles E. McLure, Replacing Separate Entity Accounting and the Arm's Length Principle with Formulary Apportionment, 56(12) Bull. Int'l Fiscal Documentation (2002).

16 Regarding the reasons why jurisdictions choose different weights in the apportionment formula, see Bharat N. Anand \& Richard Sansing, The Weighting Game: Formula Apportionment as an Instrument of Public Policy, 53(2) Nat'l Tax J. (2000).

17 Regina Ortmann, Uncertainty in Weighting Formulary Apportionment Factors and Its Impact on After-Tax Income of Multinational Groups, 184 Arqus Discussion Papers 4 (2015). 
Formulary apportionment in the European Union

Table 1 State Apportionment of Corporate Income (Formulas for Tax Year 2017 - as of 1 Jan. 2017)

\begin{tabular}{|c|c|c|c|}
\hline ALABAMA* & Double wtd Sales & NEBRASKA & Sales \\
\hline ALASKA* & 3 Factor & NEVADA & No State Income tax \\
\hline ARIZONA* & Sales/Double wtd Sales & NEW HAMPSHIRE & Double wtd Sales \\
\hline ARKANSAS* & Double wtd Sales & NEW JERSEY & Sales \\
\hline CALIFORNIA* & Sales & NEW MEXICO*(3) & $\begin{array}{l}80 \% \text { Sales. } 10 \% \text { Property \& } \\
\text { Payroll }\end{array}$ \\
\hline COLORADO* & Sales & NEW YORK & Sales \\
\hline CONNECTICUT & Sales & NORTH CAROLINA*(3) & Quadruple wtd sales \\
\hline DELAWARE (4) & Double wtd Sales & NORTH DAKOTA* & 3 Factor \\
\hline FLORIDA & Double wtd Sales & $\mathrm{OHIO}$ & N/A (2) \\
\hline GEORGIA & Sales & OKLAHOMA & 3 Factor \\
\hline HAWAII* & 3 Factor & OREGON & Sales \\
\hline IDAHO* & Double wtd Sales & PENNSYLVANIA & Sales \\
\hline ILLINOIS* & Sales & RHODE ISLAND & Sales \\
\hline INDIANA & Sales & SOUTH CAROLINA & Sales \\
\hline IOWA & Sales & SOUTH DAKOTA & No State Income tax \\
\hline KANSAS* & 3 Factor & TENNESSEE & Triple wtd Sales \\
\hline KENTUCKY* & Double wtd Sales & TEXAS & Sales \\
\hline LOUISIANA & 3 Factor & UTAH & Sales \\
\hline MAINE* & Sales & VERMONT & Double wtd Sales \\
\hline MARYLAND & Sales/ Double wtd Sales & VIRGINIA & Double wtd Sales/Sales \\
\hline MASSACHUSETTS & Sales/ Double wtd Sales & WASHINGTON & No State Income tax \\
\hline MICHIGAN & Sales & WEST VIRGINIA* & Double wtd Sales \\
\hline MINNESOTA & Sales & WISCONSIN* & Sales \\
\hline MISSISSIPPI & Sales/Other (1) & WYOMING & No State Income tax \\
\hline MISSOURI* & 3 Factor & DIST. OF COLUMBIA & Sales \\
\hline MONTANA* & 3 Factor & & \\
\hline
\end{tabular}

Source: Compiled by the Federation of Tax Administrators (FTA) TA from state sources.

\subsection{Controversial Issues}

According to existing literature, each of the three factors included in the formula raises doubts. ${ }^{18}$ For instance, the location of assets, labour and sales is sometimes difficult to identify. Valuation of assets and treatment that must be given to sales of intermediate products between companies

\section{Notes}

18 See Ana Agúndez-García, The Delineation and Apportionment of an EU Consolidated Tax Base for Multi-Jurisdictional Corporate Income Taxation: A Review of Issues and Options, (9) Tax'n Papers 47-57 (2006). 
located in different MS appear as problematic issues as well. Despite this fact, sales factor has traditionally been the most controversial one. ${ }^{19}$

Amongst the main criticisms, some authors have stated that sales factor doubles the effect of Value-Added Tax (VAT) on destination MS when it is introduced in the apportionment formula. ${ }^{20}$ Furthermore, it is commonly thought that using the sales factor harms net exporting states, who theoretically suffer a reduction of public income in favour of net importing states. ${ }^{21}$ Finally, there is no agreement about the role that sales really play in the allocation process of the corporate tax base amongst MS. This controversy is clearly reflected by McLure (2007), according to which:

While there seems to be strong support for using payroll and property to apportion income, support for also using sales appears to be much weaker. (...) Some believe that sales at destination should be included to reflect the contribution of demand to the earning of corporate income. Others counter that sales at destination have no place in the formula, because income is created where production occurs. $^{22}$

In the same line, Agúndez-García points out that:

The theoretical rationale for including gross receipts as an apportioning factor $(\ldots)$ is recognising the role that the place of demand plays in corporate profits: after all, profits would not be made if the goods were not sold somewhere. Thus, demand is thought to create company income by itself $(. .$.$) . Others (...), however, ques-$ tion whether mere demand constitutes an incomeproducing factor and, as a consequence, whether a part of the taxable income should be assigned to the demand jurisdictions solely for providing a consumer market. $^{23}$

\section{Anti-abuse rules in the proposal FOR A DIRECTIVE ON A CCCTB}

\section{I Overview}

In accordance with its earliest approach, transfer pricing leads to an optimal allocation of companies' profits to those territories where they have effectively been earned. From this perspective, it is a perfect apportionment method. In the last few years, however, companies have found incentives to manipulate transfer prices with the aim of avoiding taxes or obtaining tax advantages, so that the transfer pricing system has become an ineffective method to reach its initial goals.

It is assumed that existing incentives to aggressive tax planning will experience an important reduction with the introduction of an apportionment formula. As said in the Introduction of the European proposal on a CCCTB, this is due to the fact that chosen factors are closely linked to the place where companies develop their economic activity and, consequently, to the place where companies earn their income. This way, profits will be taxed where they are really obtained and not where companies want them to be taxed.

The truth, however, is that factors included in the apportionment formula are also prone to manipulation to a certain extent. Given that European institutions are aware of this fact, the EC's proposal on a CCCTB includes a series of anti-abuse rules.

\subsection{Labour Factor (Wages and Number of Employees)}

According to Article 33 of the proposal, employees must be included in the labour factor of the company that pays their wages. Exceptionally, when an employee is effectively working for a different company of the same group, so that the entity monitoring the employee's job and the entity paying the employee's salary are not the same, he/she must be included in the labour factor of the company that controls his/ her job.

In the second place, Article 33 establishes that the labour factor also includes those people who have not directly been hired by the company, but work effectively for it in similar or identical terms to the rest of hired employees.

Finally, Article 33.4 points out that the labour factor must include not only wages but also any kind of remuneration paid to employees as a compensation for their work, as well as costs associated with pension funds and social security. For instance, payments in kind or gifts will

\section{Notes}

19 See Walter Hellerstein \& Charles E. McLure, The European Commission's Report on Company Income Taxation: What the EU Can Learn from the Experience of the US States, 11(2) Int'l Tax \& Pub. Fin. 14, 15 (2004).

20 According to these authors, the aim of corporate taxation is to tax production and not consumption, which is already taxed by VAT in the EU. When the sales factors is included in the apportionment formula, they add, marketing countries benefit twice, as they are remunerated via corporate taxation and via VAT.

21 See Anand \& Sansing, supra n. 16, at 184.

22 Poterba, supra n. 3, at 169, 170.

23 Agúndez-García, supra n. 18, at 52, 53. 
have the same consideration as wages from the point of view of apportionment.

Undoubtedly, these three provisions can be defined as anti-abuse rules, since they try to avoid the manipulation of the labour factor (both wages and number of employees) with the only purpose of reducing its weight in those MS with higher tax rates (and vice versa). As a result of these manipulation strategies, a greater part of the group's tax base (if not the whole tax base) would be assigned to those MS with lower tax rates and, in this way, the group could obtain important tax savings.

\subsection{Assets Factor}

Assets factor is said to provide great opportunities for manipulation. Mainly, because some types of assets, such as intangible assets, financial assets or inventory, are extremely mobile. Easy access to mechanisms to separate legal and economic ownership, such as leasing, is another source of manipulation in this field.

According to the EC's proposal, intangible assets, inventory and financial assets will not be regarded when it comes to apportioning companies' income amongst MS. Without any doubt, this legal provision will contribute to fight against profit shifting more effectively, given that these three types of assets are highly prone to manipulation.

From the location perspective, Article 35 of the proposal on a CCСТB indicates that assets will be assigned to the MS where their economic owner is established. Only when the economic owner cannot be identified, will an asset be assigned to its legal owner. Again, these provisions try to avoid manipulation of assets factor with the only purpose of benefitting from tax savings.

Finally, Article 36.5 refers to the situation in which one company sells an asset to a different company of the same group and, either the same year or the following one, the same asset is sold to a third party. In that case, the asset will have to be included in the assets factor of the initial owner in order to avoid manipulation and profit shifting. Exceptionally, this anti-abuse rule will not be applied when the group demonstrates that the internal operation was due to commercial reasons.

\subsection{Sales Factor}

Concerning the definition of the sales factor, the CCCTB proposal opts for a strict regulation in order to guarantee that group's income not coming from its ordinary economic activity is excluded from the apportionment formula. This is the case of income derived from interest payment, dividends and royalties. The reason for this exclusion is closely linked to the European fight against aggressive tax planning, as this kind of income can be shifted from one MS to another in quite an easy and cheap way.

On the other hand, the EC's proposal expressly excludes from the apportionment formula positive and negative results coming from internal operations, i.e. operations between companies of the same group. Apart from not contributing to generate real profits for the group, the inclusion of such operations would oblige companies and tax authorities to use transfer pricing. Therefore, problems associated with manipulation and tax evasion would appear again.

\section{Comments on the eUROPEAN PROPOSAL FOR A CCCTB}

\section{I Flaws of the Proposal}

It is widely believed that the EC's proposal on a CCCTB will not completely eliminate the risk of tax evasion and profit shifting. ${ }^{24}$ Amongst other reasons, because the factors included in the formula are prone to manipulation to a greater or lesser extent. In addition to this criticism, I believe that the suggested formula, based on a combination of assets, labour and sales, is far from being economically consistent for three reasons.

First of all, we have to take into consideration that companies earn profits in those territories where they develop an economic activity. Economic activity includes both production and sales. Assets and labour, which represent production activity, are two productive factors. By contrast, sales contributes to generate income but is not a productive factor itself. At least, this is what economic theory tells us. The fact that a company's income is only realized when goods and services are sold does not allow us to include sales in the list of traditional productive factors (wages, assets, land, technology, knowledge, etc.).

In the second place, it is important to highlight that sales depend on production level and, in turn, production level depends on the use of productive factors. When a company decides to use only assets and labour as productive factors, as is the case, the company's sales will be a function of assets and labour.

Finally, we have to bear in mind that a company's profit is defined by the positive difference between income (sales, supply of services, etc.) and all expenses that are necessary to generate it (purchases, wages, asset costs, etc.). The suggested formula does not seem to be coherent

\section{Notes}

24 See Dirk Kiesewetter et al., Can Formula Apportionment Really Prevent Multinational Enterprises from Profit Shifting? - The Role of Asset Valuation, Intragroup Debt, and Leases, 175 Arqus Discussion Papers (2014). 
in the light of this definition, since it distributes companies' profits amongst MS based on an addition of two negative components (assets and labour) and a positive one (sales).

\subsection{Alternative Formulas}

It seems that European institutions should revise their proposal and suggest a new formula before continuing with the CCCTB negotiation process. This formula must be economically consistent and, at the same time, it must be suitable for reaching the intended objectives. Personally, I believe that two different alternatives should be discussed: a two-factor formula, based on assets and labour as productive factors, and a formula exclusively based on sales as an income generating factor. Both alternatives are coherent with Agúndez-García's opinion, according to which: 'The choice of factors and their weighting cannot really be founded on principled scientific methodology, but they should ultimately reflect the political preferences as to the purpose of corporate taxation (whether it should remunerate producing or marketing states). The only correct rule might simply be the one on which Member States can agree. ${ }^{25}$

\section{A TWO-FACTOR FORMULA FOR THE EU}

\section{I Overview}

One of the main purposes of the EC's proposal is to help European institutions in their fight against profit shifting strategies. This major advance will contribute to ensure that companies' income is taxed in MS where they have been effectively earned. As far as I am concerned, the most reasonable method to try to reach both goals at the same time consists of a formula based on two factors: assets and labour.

From an economic point of view, a formula based on these two factors is fully consistent. First, because both labour and assets are productive factors, according to economic theory. In the second place, because both assets and labour work as negative components when it comes to calculating a company's profit.

\subsection{Advantages}

Regarding its advantages, such an apportionment formula would lead to an appropriate distribution of companies' income amongst MS. As labour and assets are productive factors, the suggested formula would assign the tax base to those territories where companies produce the goods and services they subsequently sell in order to earn profits. On top of that, the resulting distribution of the tax base amongst MS would be closer to the real situation, i.e. the resulting distribution would allow the identification of those MS where value is truly generated.

\subsection{Disadvantages}

It is a fact, however, that a two-factor formula does not resolve inefficiency in location decisions nor the problem of profit shifting. First of all, we have to bear in mind that companies can decide where to locate productive factors, such as labour and assets. As opposed to what happens with sales, labour and, especially, assets are mobile to a greater or lesser extent. On the other hand, experience has demonstrated that assets and labour are prone to manipulation. Although it is true that the EC's proposal includes a series of anti-abuse rules in order to avoid this problem, some scholars are convinced that there will still be scope for factor manipulation. ${ }^{26}$

\subsection{Concluding Remarks}

Although an apportionment formula based on labour and assets will not resolve efficiency problems and will not eliminate the risk of profit shifting, I think it will notably contribute to reduce both issues. Amongst other reasons, because public administrations will find it easier and cheaper to control location of only two productive factors than continuing with the application of transfer pricing.

\section{A SINGLE-SALES FACTOR FORMULA FOR THE EU}

\section{I Overview}

The second alternative for distributing the tax base consists of a formula exclusively based on sales by destination. ${ }^{27}$ The starting point of this proposal is that none apportionment formula is able to assign companies' profits to the MS where they have been effectively earned. Accordingly, the only thing we can do is looking for a more efficient method to fight against profit shifting. Compared to a formula based on labour and assets, a formula exclusively based on sales by destination would not lead to such an accurate distribution of companies' income. However, as long as companies' income were

\section{Notes}

25 Agúndez-García, supra n. 18, at 46.

26 According to Kiesewetter et al., supra n. 24, at 2, 'Quite in contrast to the EC's view that the proposed system will offer more neutrality and less opportunities for tax planning, we expect a simple shift in tax planning strategies to occur from the calculation of the tax base to the determination of the apportionment factors.'

27 A similar proposal can be found in Avi-Yonah \& Clausing, supra n. 6, at 10-13. 
distributed on the ground of consumption, this option would notably reduce the problem of tax evasion.

\subsection{Advantages}

From my perspective, it is possible to identify at least four advantages of using a formula exclusively based on sales by destination. First of all, we have to take into consideration that, as opposed to what happens with assets and labour, sales are not a mobile factor. Companies cannot decide where to sell their products and services. They have no more option than selling in those territories where their customers are located, regardless of tax rate levels. As tax considerations would be irrelevant in this new context, productive factors would be located in those MS where they are more efficient and cost-effective. Therefore, the application of a formula exclusively based on sales by destination would imply greater efficiency in companies' decision making process.

Closely related to improvement in efficiency level, the introduction of a single-sales factor formula would reduce tax competition amongst MS. Given that tax issues would become irrelevant, MS would not have incentives to reduce tax rates in order to attract companies' interest. On the other hand, as the amount of wages, the number of employees and the total value of assets would not affect companies' tax debt, this method would lead to a growth of employment and investment rate in aggregate terms. ${ }^{28}$ This argument, however, is harshly criticized by Mazerov, according to whom 'A thorough consideration of a large body of research on the impact of state business tax policy on economic development and of all the incentives created by a sales-only formula points to the conclusion that adoption of such a formula is likely to be relatively ineffectual, potentially counterproductive, and not cost-effective incentive for job creation and investment. ${ }^{, 29}$

In the second place, single-sales factor formula would contribute to fight against tax evasion and profit shifting more efficiently. Amongst other reasons, this apportionment method is based on a close connection between corporate income tax and value added tax, so public authorities would be able to take advantage of synergies in control activity. On top of that, we have to bear in mind that location of sales has traditionally been quite a controversial issue. Nevertheless, if we decided to apply a single-sales factor formula based on destination to apportion income, this problem would be resolved with the application of VAT location rules. ${ }^{30}$ In this sense, we have to take into consideration that 'VAT is established in most countries and even harmonized in the EU. Compared to the development of a new set of rules, resorting to the approved VAT system would save administrative costs and introduction costs alike'. ${ }^{31}$ Furthermore, this option 'could minimize the costs of data collection, because the VA key could work with data already collected and reported for the EU VAT system'. 32

Thirdly, as the suggested formula is exclusively based on one factor, it would be easier and cheaper for public authorities to administer and control operations between related companies. The connection between corporate income tax and VAT would also contribute to achieving this result.

From a macroeconomic perspective, this system could lead to better distribution of wealth amongst MS. Given that companies' income would be distributed amongst MS on the grounds of sales, net importing states would experience an improvement in terms of public income, whilst net exporting states would suffer an income loss. ${ }^{33}$ Bearing in mind that net importing states' balance of payments is negative by definition, the growth of public income would undeniable imply an improvement of their economic situation in comparative terms. In accordance with this argument, Avi-Yonah and Clausing (2007) refer to the 'the widespread belief that imposing taxes on imports and exempting boosts national competitiveness and reduces trade deficits'. ${ }^{34}$

\subsection{Disadvantages}

Concerning its drawbacks, the starting point of this alternative is that none apportionment formula is able to assign companies' profits to those territories where they have effectively been earned. Therefore, a formula based on sales as the only apportionment factor would lead to an inadequate or imprecise distribution of companies' tax base amongst MS. Basically, because such a method ignores the role of assets and labour as income generating factors. According to many scholars, however, the purpose of the apportionment formula is not to search for the 'true' source of income, but 'assigning

\section{Notes}

28 According to Anand \& Sansing, supra n. 16, at 184, 'a state using DWSF [double weight the sales factor] will be more attractive place to locate the property and payroll of a business enterprise operating in multiple states than a corresponding EWF [equal weighted formula state]'

29 Mazerov, supra n. 12, at 38.

30 Concerning advantages related to a close connection between corporate income tax and VAT, see Agúndez-García, supra n. 18, at 69-85.

31 Norbert Herzig et al., Between Extremes: Merging the Advantages of Separate Accounting and Unitary Taxation, 38(6/7) Intertax 347 (2010).

Agúndez-García, supra n. 18, at 83 .

A demonstration can be found in Kelly D. Edmiston, Strategic Apportionment of the State Corporate Income Tax. An Applied General Equilibrium Analysis, 2 Nat'l Tax J. (2002).

34 Avi-Yonah \& Clausing, supra n. 6, at 12. 
income taxing rights across the countries with a "reasonable" claim to it'. ${ }^{35}$

On the other hand, changing to a sales-factor formula could lead to a completely different situation in terms of income distribution amongst MS for tax purposes. ${ }^{36}$ Although it is not possible to predict the specific results of the proposal from an aggregated point of view, individual losses and profits could be noticeable. I suggest an example to illustrate this statement.

Company A has its residence in Spain. This company produces all its goods in Spain, but sells all its production in France. According to current law, if company A decided to directly sell its products to French customers, i.e. without a permanent establishment (PE) in France, the whole income of the company would be taxed in Spain. If we decided to use a single-sales factor formula to allocate companies' profits, however, the whole income of company A would be taxed in France.

On the other hand, if company A decided to sell its products in France not directly, but through a PE in that territory, the result would also be quite different. According to current legislation, A's income would be taxed both in Spain and in France. Nevertheless, if a single-sales factor formula were applied, the whole income of company A would be taxed in France. Irrespective of the followed strategy, therefore, A's whole income would be taxed in France because it is here that their products are sold and effectively consumed.

\subsection{Concluding Remarks}

Undoubtedly, the application of a single-sales factor formula could substantially change the geographical distribution of companies' tax base amongst MS, making the approval of a new set of rules difficult. ${ }^{37}$ However, I disagree with those scholars who refer to changes in tax base distribution as a negative aspect of the European proposal. Furthermore, even if this result was regarded as a drawback, it is vital to take into consideration the large number of advantages that the proposal would imply. For instance, lower compliance costs for companies, lower monitoring costs for public administrations, greater efficiency in companies' location decisions and less risk of tax evasion.

On the other hand, it is a fact that some experts have pointed out that using a formula exclusively based on sales would lead to a double taxation on consumption. In relation to this assertion, however, I think it is necessary to make a distinction between taxing companies' income, on the one hand, and locating companies' income, on the other. When we decide to use a single-sales factor formula we are only choosing a method to distribute companies' profits amongst MS. However, those profits are going to be taxed anyway, irrespective of the applicable sharing mechanism. In other words, "the inclusion of a factor in the formula does not imply a new taxation of this factor but the allocation of taxing rights among taxing jurisdictions on the consolidated tax base (the individual tax bases would be taxed in any case)'. ${ }^{38}$

\section{SUMMARY AND DISCUSSION}

The main purpose of the proposal on a CCCTB is to replace transfer pricing with a new method for allocating companies' income. As a result, the new method is expected to combat profit shifting strategies and to ensure that companies' income is taxed where it has been earned. After analysing different available alternatives, however, we conclude that it is impossible to design a perfect apportionment formula.

The EC's initial proposal for a sharing mechanism is pretty similar to the so-called Massachusetts formula, as it is based on three equally weighted factors: assets, labour and sales. To my mind, however, such a formula is not consistent from an economic point of view. Amongst other reasons, because it combines two productive factors (assets and labour) with a component like sales, which is not a productive factor and, at the same time, is a function of assets and labour. On top of that, experience has shown that there is scope for profit shifting when the Massachusetts formula is applied.

The two alternatives we suggest in this article are a two-factor formula, based on assets and labour, and a onefactor formula, exclusively based on sales by destination. Initially, the first option leads to a more accurate allocation of companies' income. Nevertheless, it does not resolve three main problems: inefficiency in companies' decisions about location and investment, profit shifting and tax evasion.

The second option, for its part, leads to a worse distribution of companies' profits amongst MS, since it completely ignores the role of assets and labour as income generating factors. However, its contribution to the European fight against profit-shifting strategies is highly relevant.

\section{Notes}

35 In relation to this issue, see Agúndez-García, supra n. 18, at 33-37.

36 See Clemens Fuest et al., How Would the Introduction of an EU-wide Formula Apportionment Affect the Distribution and Size of the Corporate Tax Base? An Analysis Based on German Multinationals, 14 Int'l Tax Pub. Fin. (2007)

37 In the same line, see Agúndez-García, supra n. 18, at 53.

38 Common Consolidated Corporate Tax Base Working Group, An Overview of the Main Issues that Emerged During the Discussion on the Sharing Mechanism SG6 Second Meeting - 11 June 20079 (2007). 
In conclusion, it is clear that none apportionment formula, technically correct from an economic point of view, can help us to reach all the objectives described in the European proposal at the same time. Given this situation, it seems that European institutions must answer a question before making any decision about the sharing mechanism: for the convenience of the EU, does it make sense to renounce an accurate distribution of companies' income amongst MS in favour of the fight against profit shifting? 